\title{
Witness for the Prosecution: The Civil War Letter of Lieutenant George Taylor
}

\author{
Author: Kim Allen Scott
}

"This is the final version of record of an article that originally appeared in Arkansas Historical Quarterly in 1989."

Scott, Kim Allen. "Witness for the Prosecution: The Civil War Letter of Lieutenant George Taylor." Arkansas Historical Quarterly 48, no. 3 (1989): 260-271.

Made available through Montana State University's $\underline{\text { ScholarWorks }}$ scholarworks.montana.edu 


\title{
Witness for the Prosecution: The Civil War Letter of Lieutenant George Taylor
}

\author{
By KIM ALLEN SCOTT* \\ Special Collections, University of Arkansas Libraries \\ Fayetteville, Arkansas 72701
}

\begin{abstract}
A
PROSECUTOR MUST PRESENT the jury with evidence against the defendant which is believable beyond a reasonable doubt. Testimony based on hearsay or the recollections of a witness several years after the crime are always subject to damaging critique by the defense. To bolster a case based on a stale reminiscence, the prosecution may use corroborating evidence: the same story told by two different parties. However, if a sharp defense attorney can show that both sources are of equal antiquity, the corroboration strategy can still be easily defused. The best testimony for substantiating old stories is a witness deposition taken immediately after the crime was committed. The introduction of such evidence can confirm the truth of the dated accounts and win the case for the prosecution.

The sacking of Fayetteville, Arkansas, by Confederate forces in February 1862 , is the "crime" we wish to examine in this paper. Before the jury of our readers, we shall present a brief narrative of the event, examine four eyewitnesses which have been questioned by many investigators over the years, and finally introduce new testimony from Lieutenant George Taylor of the Seventeenth Arkansas Infantry, who, until the publication of this paper, has been keeping his version buried in an Oklahoma attic. While Taylor's story adds little which is new to our understanding of Fayetteville's unfortunate plight, it will prove to be an
\end{abstract}

*The author is processing archivist for the Special Collections Department, University of Arkansas Libraries, Fayetteville. 
eloquent version of the incident which substantiates another source that some historians have felt to be most biased.

Confederate forces occupied the town of Fayetteville shortly after the secession convention voted Arkansas out of the Union on May 10, 1861. The first troops to reach the prosperous Ozarks town were the "Hempstead Rifles," a band of volunteer infantrymen from Washington, Arkansas. Shortly after the Rifles set up camp, the Third Louisiana Infantry also arrived to pitch their tents on the grounds of Arkansas College. Aside from brief forays into the Indian Territory and Missouri (most notable being the Wilson's Creek campaign in August 1861), southern troops remained in the Fayetteville and Washington County area until February 1862, when the advancing Union army caused them to withdraw south of the town to the safety of the Boston Mountains. Fayetteville had become quite a supply center by this time and to prevent the yankees from capturing the quartermaster's stores, Brigadier General Benjamin McCulloch decided to turn his army loose to carry away what foodstuffs they could. There followed a brief period of riotous anarchy among the rebel soldiers as they looted not only their own commissary supplies, but also the homes and shops of Fayetteville civilians. Once the Confederates made their safe withdrawal, a party of cavalrymen returned to Fayetteville and set fire to many of the town's principal buildings. When Union troops under the command of Brigadier General Alexander Asboth arrived on February 23, they found a smoldering set of ruins and a handful of loyalist citizens who welcomed the yankees as liberators. ${ }^{1}$

Almost every secondary account of Fayetteville's sacking is based on the recorded impressions of four people who were present at the time: Marian Tebbetts Banes, an eleven-year-old girl; Washington Lafayette Gammage, a surgeon with McNair's Brigade; William H. Tunnard, sergeant of Company $\mathrm{K}$, Third Louisiana Infantry; and William Baxter, a preacher and president of Arkansas College. ${ }^{2}$ Each one of these people

\footnotetext{
${ }^{1}$ United States War Department, The War of the Rebellion; A Compilation of the Official Records of the Union and Confederate Armies (Washington, D. C., 1880-1901), Ser. I, Vol. VIII, p. 70, cited hereinafter as $O . R$.

${ }^{2}$ Marian Tebbetts Banes, The Journal of Marian Tebbetts Banes (Fayetteville, Ark.,
} 
told his version of the story to different audiences years after the event occurred.

The testimony of Marian Tebbetts Banes is the easiest to discount. Written in 1941, nearly eighty years separate this written record from the child's experience. ${ }^{3}$ Marian did not record anything about southern soldiers sacking the town, but she did state firmly that the fires were started directly on the orders of General McCulloch. She even insisted that General Sterling Price tried to reason with McCulloch over the burning order, but she neglected to explain how she became privy to this high-ranking consultation.

The next two witnesses called to the stand are Confederate soldiers: Dr. Washington L. Gammage and Sergeant William H. Tunnard. Gammage, an Arkansan, wrote his version in 1864, just two years after the event and while addressing an audience still at war with the United States. He stated that on the morning of February 19, 1862, he saw southern troops breaking into stores, smokehouses, and private residences to plunder. He added that Fayetteville citizens also helped in the carnival atmosphere when they joined the soldiers in stealing the quartermaster stores. While Gammage called the looting "one of the most disgraceful scenes I ever saw," his assertion of civilian participation at least helped soften the condemnation of his comrades and he neglected to mention anything about the subsequent burning of the town. ${ }^{4}$ Sergeant Tunnard

1977); Washington Lafayette Gammage, The Camp, The Bivouac, and the Battlefield (Selma, Ala., 1864); William H. Tunnard, A Southern Record: The History of the Third Regiment of Louisiana Infantry (Baton Rouge, La., 1866); William Baxter, Pea Ridge and Prairie Grove, or, Scenes and Incidents of the War in Arkansas, reprint of the original volume published in 1864, ed. Hugh Park (Van Buren, Ark., 1957). An additional eyewitness source which has not been examined in this paper can be found in William Watson, Life in the Confederate Army, Being the Observations and Experiences of an Alien in the South during the American Civil War (London, 1887). Watson, who also served in the Third Louisiana Infantry, has not been quoted as often as the other sources, probably due to the obscurity of the publication and the relative lack of significant detail in his description.

${ }^{3}$ Banes, Journal, 88-89. When one considers the uncertainty of an octogenarian's memory, coupled with the fact that the original manuscript of Banes's reminiscence is no longer available for comparison against the published version, it is amazing how much weight historians still place on this apocryphal source.

${ }^{4}$ Gammage, The Camp, 23. 
documented his version of the sacking in 1866, writing to a public already infected with the "Lost Cause" romanticism so prevalent among Reconstruction-era southerners. He also claimed that what he saw in Fayetteville on February 20 "beggared all description" as the soldiers broke into stores and unoccupied houses, but he actually described only the distribution of commissary stores among the rebels rather than household goods. ${ }^{5}$ Tunnard dismissed the burning of Fayetteville as a "military necessity no one could question ... who at all comprehended the situation of affairs." 6

The most damaging witness against the Confederates is William Baxter, an ardent Unionist and resident of Fayetteville in 1862. Like Gammage, Baxter wrote his version just two years after the event but Baxter published his account for northern readers. His version is so blatantly biased toward the Union cause that even when it was reprinted in 1957, editor Hugh Park felt compelled to advise the reader: "We are aware that this volume may still stir some feeling of strife in those who yet feel the pangs of the Southern conflict; and no doubt it will be met in some quarters by charges of 'Yankee propaganda'."'

How did Baxter describe the looting of Fayetteville? Apparently with complete honesty. He blamed the Confederates entirely for throwing open the town for plunder, but did not fail to indict his own neighbors for joining with the soldiers in stealing the commissary stores. Once the attention of the mob turned to private residences and shops, however, the preacher's accusations settled entirely on the military participants:

So general had the work of destruction and plunder become that it was impossible to find a single soldier who did not possess some evidence of being carried away with the spirit of the hour. Here was one with a cigar box half filled with sugar, another with a

\footnotetext{
`Tunnard, A Southern Record, 125-126.

${ }^{6}$ Ibid.

${ }^{7}$ Hugh Park, introduction, Pea Ridge and Prairie Grove, by William Baxter, p. iii. For another historian's assessment of Baxter's prejudice see Conaly Bedell, "The Terror in Fayetteville," unpublished manuscript: Fort Smith, Arkansas, 1966 (University of Arkansas Libraries, Fayetteville), 38-40. Bedell asserts that Baxter's version is the least biased of any available, but still admits that the educator's partisan viewpoint heavily influences his testimony.
} 
pair of lady's gaiters sticking out of his pocket; this had a pair of baby's shoes, that, some fine lace. . . . Some contented themselves with what really belonged to them-the army stores . . . but what could others want with fine articles of ladies' wear and, as I noticed in one case, a thermometer ? ${ }^{8}$

Baxter's graphic picture of soldiers running amok in Fayetteville can finally be validated with contemporary eyewitness testimony from Lieutenant George Taylor, Company $\mathrm{H}$, Seventeenth Arkansas Infantry. Taylor wrote down what he saw in a letter to a friend just a few days after the sacking while the event was still fresh in his memory, and his version stands alone as the only contemporary statement on Fayetteville's sad misfortune. ${ }^{9}$

George Taylor was born in Loudoun County, Virginia, on March 12, 1838. He received a good education in the Old Dominion, and by age eighteen he worked as a clerk in an Alexandria business firm. ${ }^{10} \mathrm{He}$ drifted west the next year and settled in Washington, Arkansas, where he found another clerk's position at the drygoods firm of J. S. Britt. He quickly established a reputation for honesty and integrity among the Hempstead County business community and gained competence as a skillful accountant. ${ }^{11}$ As the crisis of 1861 approached, George enlisted with a local militia group, the Hempstead Rifles, and accepted a commission as third lieutenant of the unit. On May 4, 1861, the Rifles traveled to Little Rock, and then to Fayetteville where they were mustered into the Third Arkansas State Troops as Company B. ${ }^{12}$ A splendid looking

\footnotetext{
${ }^{8}$ Baxter, Pea Ridge, pp. 49-50.

${ }^{9}$ George Taylor, letter to Rebecca Stirman, March 3, 1862, Rebecca Stirman Davidson Papers (Special Collections Department, University of Arkansas Libraries, Fayetteville). While it is reasonable to suppose that out of the thousands of soldiers who passed through Fayetteville on February 20, 1862, many wrote letters home, none have appeared in print to date.

${ }^{10} \mathrm{~W}$. Hyde and H. L. Conard, eds., Encyclopedia of the History of St. Louis (St. Louis, 1899), Vol. IV, p. 2222-2223.

${ }^{11}$ Sam Williams, Sam Williams; Printer's Devil (Hope, Ark., 1979), 277. “A betterhearted man, a more square dealing business man, or a more thorough gentleman than George Taylor never walked upon two legs," is the assessment given by Sam Williams who knew Taylor both before and after the war.

${ }^{12}$ Donald Montgomery, "Far From Home and Kindred; The History of Confederate
} 
body of soldiers, the Rifles, along with the Third Louisiana Infantry, created quite a stir among the ladies of Fayetteville with their neat gray uniforms and plumed officers' hats. ${ }^{13}$ One young woman, Miss Rebecca Stirman, particularly caught the eye of Lieutenant Taylor and between drilling and picket duties the soldier used his free time to visit with the girl as much as possible.

By the late summer of 1861 the Hempstead Rifles found themselves in southwest Missouri with other southern troops commanded by generals Benjamin McCulloch and Sterling Price. At their encampment along Wilson's Creek just southwest of Springfield, Lieutenant Taylor and his comrades faced the fire of Union troops for the first time on August 10. The Hempstead Rifles suffered horribly as they defended an artillery unit commanded by Captain William E. Woodruff, Jr., taking casualties not only from the enemy, but also from excited southern forces who fired accidentally into their ranks. ${ }^{14}$ Following the battle of Wilson's Creek, the Third Arkansas State Troops voted to disband rather than enter the regular Confederate army. Some of the Hempstead Rifles went back home, but others, including George Taylor, reenlisted in other Confederate units. At a reorganization of troops at Fort Smith in December, Taylor and his comrades from the Hempstead Rifles were placed in Company $\mathrm{H}$, Seventeenth Arkansas Infantry and sent back to the northwest corner of Arkansas for the winter. ${ }^{15}$

Bentonville, Arkansas, became the next garrison for the Seventeenth, and George's merchandising talents were tapped by Colonel Frank Rector when he appointed the former clerk as quartermaster for the regi-

Companies Raised in Hempstead County," Journal of the Hempstead County Historical Society, Vol. XII (Spring 1988), 15-16.

13 Banes, Journal, 89; Baxter, Pea Ridge, 38-39. Both of these sources comment on the elegance of the southerner's uniforms. While Banes's testimony may be discounted on other points, a childhood memory of colorful uniforms is plausible enough to cite here.

${ }^{14}$ Montgomery, Far From Home, 15.

${ }^{15}$ U. S. War Department, Compiled Service Records of Confederate Soldiers Who Served in Organizations from the State of Arkansas, M311, George Taylor, Company H, Seventeenth (Griffith's) Arkansas Infantry, Record Group 109 (National Archives, Washington, D. C.). This source lists Taylor's enlistment with the Seventeenth Arkansas to be at Fort Smith on December 4, 1861. 
ment. ${ }^{16}$ Taylor's duties kept him in Bentonville during the opening weeks of 1862, but he still found time to visit Fayetteville in order to call on Miss Stirman. The rapidly unfolding events of the war put an early end to Taylor's residence in Bentonville, however. A sudden advance by Union troops under the command of Brigadier General Alexander Asboth arrived at the town on February 18, forcing a hurried evacuation by the rebels. Taylor himself barely escaped capture before the Yankees surrounded the town, losing his horse, his office papers, and his account books in the process. ${ }^{17}$ The Seventeenth Infantry fared no better: they suffered the humiliating capture of the regimental colors along with many sick and wounded left behind in Bentonville hospitals. Asboth continued his dogged pursuit of the Confederates, and when George arrived at Fayetteville on February 20, he found many of the town's inhabitants had fled in response to the invasion, including Rebecca Stirman who had gone to the relative safety of Van Buren. The rebel high command chose not to hold Fayetteville, and as quartermaster for the Seventeenth Infantry, Taylor had the responsibility of distributing the commissary stores to the troops as they prepared to evacuate the town. $\mathrm{He}$ remained at his post until the morning of February 23, scrupulously recorded the disbursement of a dozen pairs of shoes to members of Company $\mathrm{D}$, and again narrowly avoided capture when Asboth's men arrived shortly after 11:00 a.m. ${ }^{18}$ He rejoined the southern army at their camp in the Boston Mountains south of town and, while a new offensive was being planned from this stronghold, Lieutenant Taylor took pen in hand to write a letter to his friend Rebecca.

${ }^{16}$ U. S. War Department, Compiled Service Records, George Taylor, Company H, Seventeenth (Griffith's) Arkansas Infantry; Frank Rector, Seventeenth (Griffith's) Arkansas Infantry. Taylor's first appointment as quartermaster in his service record is dated February 13, 1862, but in the service record of Col. Frank Rector is a clothing requisition form, dated Bentonville, January 13, 1862, signed by Taylor in the capacity of quartermaster to the regiment.

${ }^{17}$ O. R., Ser I, Vol. VIII, p. 63-64.

18 U. S. War Department, Compiled Service Records. Frank Rector, Seventeenth (Griffith's) Arkansas Infantry. An additional requisition form in Rector's file, signed by George Taylor and dated Fayetteville, February 23, 1862, documents the disbursement of the shoes. Taylor could not have lingered in the city for more than a few hours that day since General Asboth reported taking the town by 11:20 a.m. See O.R., Ser. I, Vol. VIII, p. 69. 
Rebecca saved Taylor's letter, along with dozens of others she received from her brother Erasmus, who also served in the southern army. The letters were kept in the family for generations until 1985 when they were offered for sale to the Special Collections Department of the University of Arkansas Libraries by descendants living in Tulsa, Oklahoma. The letters of Erasmus Stirman were published almost immediately, but for some reason Taylor's note to Rebecca was not deemed relevant to the collection and excluded from the work. ${ }^{19}$ Now, after keeping his silence for 127 years, it is time to call Lieutenant George Taylor to the stand and hear his testimony:

Camp on Boston Mountain March 3, 1862

Miss Becca,

I have determined to write you a few lines this morning, and I have no excuse to make, or apology to offer for troubling you, other than what some little boy might say - "Just because I want to"- But I am not entirely sure that the permission you once gave me to write you just one letter has been countermanded or withdrawn, and so I'll take it for granted that it has not-Tell me if you are a little displeased or vexed somewhat when you receive this letter, and as I used to promise a grim old Virginia schoolmaster,- -I'll never do so again"- But if you knew how cold it is up here in these dismal mountains, and how that I can hardly hold my pen in my fingers, you would readily believe that I was not writing to-day for a mere pastime or a particular fancy to put my sundance thoughts on paper.

I have thought of you often, since you have become a Refugee, if I may so call it. (not much before you know) I called at your old home in Fayetteville a few minutes when our regiment passed through. Mrs.

\footnotetext{
${ }^{19}$ Pat Carr, In Fine Spirits: The Civil War Letters of Ras Stirman (Fayetteville, Washington County Historical Society, 1986). All letters in Carr's book were addressed to Rebecca Stirman, and one from a soldier in a Kentucky prison camp was included with those written by Ras. As a result, it is somewhat puzzling why George Taylor's letter was excluded from this publication. We should point out that we have also excluded a letter written by Taylor found in the same collection. A short note, dated January 25, was sent by the young lieutenant to Rebecca, but it is nothing more than a formal request to continue their friendship by exchanging letters.
} 
Pollard told me that you and Miss Annie ${ }^{20}$ had gone to Ft. Smith, but she was determined to brave the storm - Not many ladies had remained. Mrs. Lee and I think Mrs. Davidson ${ }^{21}$ among the few. I am very glad that you are safely away, and I doubt not having as near a pleasant time as possible, until your home shall be restored, as it certainly soon must be -

Fayetteville presented indeed a sad spectacle when we passed through on the 20th. I could not but contrast the beautiful quiet little town of last May when we were so heartily welcomed to the then devastation and waste and ruin manifest all around. Heaven help a country where an army must linger, be it friend or foe. What Citizens now left in Fayetteville, seemed perfectly panic-stricken - seemed to be utterly regardless of anything like protection of property. Stores all along Main Street were thrown open to the Missouri and Arkansas soldiers.

Amid the destruction it could not but be amusing to see great heavybearded fellows carrying around fancy little toys - rattlers, made to amuse very small juveniles. Bonnet frames - old French flowers nearly every man had a looking-glass.

While the disastrous results of this unexpected invasion are incalculable, yet it will prove doubtless in many respects beneficial. It has thoroughly aroused Arkansas, and she has been sleeping in fancied security too long. Thousands are now rallying to the standard to protect our

20 "Mrs. Pollard" was the wife of Dr. Thomas Pollard, a Kentucky physician and prominent local secessionist. "Miss Annie" was Annie Pollard, their sixteen-year-old daughter. Rebecca Stirman lived with this family to whom she and her brothers were related. The Pollards were very active in equipping southern soldiers. Mrs. Pollard presented the flag to Ras Stirman's company on May 2, 1861, and Dr. Pollard purchased a large supply of lead from a Missouri mercantile firm a few days afterwards. William Baxter mentions a violent argument in the Fayetteville telegraph office with an unnamed physician that was probably Pollard. See Baxter, Pea Ridge, 22-23; "A Flag Presentation," Flashback, VIII (March 1958), 15; B. K. Hersey \& Co., receipt issued to W. T. [sic] Pollard, May 19, 1861, Mcllroy Family Papers (Special Collections Department, University of Arkansas Libraries, Fayetteville).

21 "Mrs. Lee" was most likely Mrs. Hanson Lee, the wife of a Prairie Township farmer. These are the only Lees listed as living in Washington County in the 1860 census. "Mrs. Davidson" was Mrs. Nancy Murphy Davidson, wife of Elijah Davidson, a carpenter from Kentucky who settled in Fayetteville around 1859. Davidson's son, Benjamin R. Davidson, would eventually marry Rebecca Stirman in 1876. 
frontier. The delusive self-assurance that Arkansas is secure, has been alas, suddenly and terribly destroyed.

"The Invaders foot is on her shore,

His hand is at thy temple door,

-Dear Fayetteville."

But I cannot think it will be so for long. The Federal army has made but little advance for a week past. The signs of the times indicate a speedy forward movement of the Southern army. Just wait now to hear of the Dutch and Yankees being run to the St. Louis. Otherwise you'll see us coming on the double quick through Van Buren.

Our old garrison, Bentonville, is one heap of ashes. Every few days one of the boys of the regiment left at the hospital there comes straggling in, frightened and forlorn, with a monstrous story of a hair breadth escape. Over in Prices camp a few days ago, I saw Clay Robards ${ }^{22}$ wouldn't you like to have seen him? He told me that one of "Brother Raz's" Lieutenants had been so unfortunate as to fall into the hands of the Dutch. He had gone to see his sweetheart - poor fellow. Such noble daring deserved a better fate. But I think just to get to see $m y$ sweetheart now I would submit to most anything. (If I had one)

Col. Rector told me yesterday that he had seen "Miss Beck" in Van Buren, and had some talk with her. But he is so bewildered, so completely lost to the recollection of everything save the fact of being married, as to have forgotten what she said. You know I enquired.

But I'm afraid I'm trespassing too much on your patience. I hope you will not think I have taken an undue liberty in writing to you - even though I have had nothing of particular interest to you to communicate. I have tried not to lose sight of the relations I sustain towards you - will it ever be so? Somehow, somehow, I cannot but hope and believe that it will not.

It may be a happy delusion - so let it be.

I have but little fear of the result of the approaching struggle, come when it may. Van Dorn, McCulloch, Price and McIntosh are all here -

\footnotetext{
${ }^{22}$ Two officers by the name of Robards served in the First Battalion (Stirman's) Arkansas Cavalry; Capt. George C. Robards of Company E, and Capt. H. C. Robards, Company F. See U. S. War Department, Compiled Service Records.
} 
It may cost much, and many a brave true southern heart may sleep cold in its bosom.

"But dearer the grave or the prison, Illumed by one patriots name, Than the trophies of all who have risen, On Liberty's ruins to fame."

Goodbye

I hope I may see you soon

Truly your friend

George Taylor

Just a few days after writing his letter to Rebecca, Taylor and his regiment again faced the enemy, this time on the western portion of the Pea Ridge battlefield, but their luck proved no better than it had been at Bentonville the previous month. In rapid succession, General McCulloch and Colonel McIntosh died from enemy fire, and the third ranking officer on the field, Colonel Louis Hebert, fell prisoner to the yankees. In the confusion following these disasters, Brigadier General Albert Pike took command but was unable to sustain the attack. The southerners were cut off from their supply train and, unable to determine conditions on the eastern portion of the field, retired from the battle on March 8. They scattered across the northwest Arkansas countryside, and when Colonel Rector conferred with Pike later that day they decided to disband the Seventeenth Arkansas and let the men shift for themselves. ${ }^{23}$ Taylor and his comrades hid their rifles in a cave and continued their retreat from the pursuing Union forces in small groups. ${ }^{24}$ The regiment did not reassemble until later that spring in Mississippi where they fought with other units under the command of General Sterling Price. As late as September 1862, members of the Seventeenth still felt compelled to answer critics for the regiment's inglorious action after Pea Ridge. $^{25}$

\footnotetext{
${ }^{23}$ O. R., Ser. I, Vol. VIII, p. 292.

${ }^{24}$ The rifles that Rector's men hid were discovered by the enemy on March 15 . See ibid., p. 618.

${ }^{25}$ Little Rock Arkansas Gazette, September 6, 1862.
} 
Taylor stayed with the rebel army until the bitter end. He apparently figured his romance with Rebecca did not look promising because he married Miss Sarah Conway, the daughter of a prominent Washington, Arkansas, physician in 1863 . By that time, the quartermaster lieutenant was in charge of the supply depot at Fulton, Arkansas, and working towards a promotion to captain. Following the war, George Taylor drew on his vast mercantile experience to operate his own business in Washington until 1880, when he moved to St. Louis to pursue a career as a cotton broker. He died there in $1893 .{ }^{26}$

The witnesses have spoken, the case has been presented. Now it is time for the jury to retire to their deliberations. Regardless of the verdict, it must be admitted that this simple letter from a lovesick Confederate officer to his lady friend has certainly amplified the testimony that has gone before, and perhaps helped us to better understand what really happened in Fayetteville during the terrible days of February 1862.

${ }^{26}$ Hyde and Conard, Encyclopedia, Vol. IV, pp. 2222-2223. 